\title{
Supportive Intervention Challenges for Patients with Breast Cancer: A Systematic Review
}

\author{
Mohammad Reza Zaker ${ }^{1}$, Amin Safaripour ${ }^{2}$, Sima Rahdaneh Zade Sabegh ${ }^{3}$, \\ Samira Barjasteh ${ }^{4}$
}

${ }^{1} \mathrm{MSc}$ in Critical Care Nursing, School of Paramedical, Urmia University of Medical Sciences, Urmia, Iran. ${ }^{2}$ Medical Student, Faculty of Medicine, Urmia University of Medical Sciences, Urmia, Iran. ${ }^{3}$ Master student of psychiatric nursing, Nursing and Midwifery School, Urmia University of Medical Sciences, Urmia, Iran. ${ }^{4} \mathrm{Ph} . \mathrm{D}$. in Reproductive Health, Nursing and Midwifery School, Tehran University of Medical Sciences, Tehran, Iran.

\begin{abstract}
Background: Cancer and its treatment can have a profound effect on the appearance of the patient, the aim of this systematic review was to identify challenges among patients with breast cancer and the effective intervention for coping it. Materials and Methods: This systematic review that was conducted based on the Preferred Reporting Items for Systematic Reviews and Meta-Analyses (PRISMA) guidelines between January 2000 to December 2018. The keywords searched included: "breast cancer," "breast neoplasm," "breast tumor," "educational intervention," "cognitive program," "body image," "supportive intervention," "family," "behavioral therapy," "counselling," "husband," and "spouse,". The Google Scholar, ISI Web of Science, Science Direct, PubMed and Scopus databases were searched. Results: After screening and review of article eligibility, ten were included in the study. The selected articles were compared regarding the aims of interest. The results showed some effective factor in the improvement of patients with breast cancer including family support, supportive programs, physically and psychologically support with family and relatives, holistic care, psychological screening and consultation, social support, family involvement in the treatment process of women with breast cancer. Conclusion: According to the results, the most problem of all articles was body image and the best effective way is family support.
\end{abstract}

Keywords: Body image-breast- cancer- family support-social support

Asian Pac Environ Cancer, 4 (1), 19-24

\section{Introduction}

Breast cancer is the most common cancer among women, which can be prevented because it has a good prognosis, and more than 1.1 million women worldwide have recently been diagnosed with breast cancer [1]. Breast cancer in Asia, including Iran, is one of the most common cancers and the second leading cause of cancer deaths among women, with an incidence of breast cancer of 22 cases per 155,000 persons in Iranian women. According to available statistics, the most commonly occurring incidence of breast cancer in developing countries, including Iran, is one decade below than advanced countries [2]. On the other hand, the breast is associated with femininity, attractiveness and gender of women [3], and the incidence of this disease affects women's feelings
Submission Date: 12/05/2021 Acceptance Date: 01/07/2022

\footnotetext{
Corresponding Author:

Dr. Samira Barjasteh

Ph.D. in Reproductive Health, Nursing and Midwifery School, Tehran University of Medical Sciences, Tehran, Iran.

Email: samira_barjaste_70@yahoo.com
} 
reducing the complications of the disease and treatment. It is suggested that in order to improve the quality of life of women with breast cancer undergoing chemotherapy, it is suggested that special attention should be paid to the role and place of the family support for participation in the therapeutic and clinical interventions process [8]. In this regard, the results of the studies showed the effect of family-based educational and supportive measures on the reduction of physical problems such as gastrointestinal symptoms associated with chemotherapy, as well [9].

The greater the family support for the patient, the greater the probability of recovery and the use of the problem-oriented approach [8]. Regarding the effect of family counseling on reducing the complications of the disease and treatment, it is recommended to pay particular attention to the role and place of the family for participation in improving the quality of life of women with breast cancer under chemotherapy in the process of therapeutic and clinical interventions and patient support [10]. Accordingly, the aim of this study was to review the effective challenges of supportive-therapeutic interventions in patients with breast cancer during 2000-2018.

\section{Materials and Methods}

This study was a systematic review research. The present review was carried out according to Preferred Reporting Items for Systematic Reviews and MetaAnalysis (PRISMA) guidelines (Moher et al., 2010).

\section{Search strategy}

In order to study the published articles in this field, internal databases for Persian articles, including SID, MagIran, IranMedex, and also www.irandoc.ac site for dissertations were reviewed as well as PubMed, ISI web of knowledge and Google Scholar databases were assessed to study English articles by Dec, 2018. The key words used in this search were "breast cancer," "breast neoplasm," "breast tumor," "educational intervention," "cognitive program," "body image," "supportive intervention," "family," "behavioral therapy," "counselling," "husband," and "spouse," or a combination of them in medical subject indexes or abstracts. The list of references in the specified articles were also reviewed for further relevant studies.

\section{Inclusion criteria}

After collecting articles, their titles were entered into the reference software to remove the duplications using this software as well as the re-reading of the titles. In the next step, by reviewing the titles and abstract, the studies that were not dealing with the aim of our study were excluded and then, the abstract of the article as well as the full text, the relevance of the articles were studied. Studies were limited to studies that were performed only on humans.

A minimum of 8 score of 12 score about quality of methods, data collection tool and population according to Table 1 were included in the final review for each publication. Publications that acquired 8 scores and higher were selected for further data extraction and analysis. Finally, the studies published in English were included in this systematic review. When several studies from a single cohort or population are published, only the results from the latest study find the conditions necessary to enter this analysis.

\section{Exclusion criteria}

Publications that the full text was not available and articles that published in non-English journals were excluded.

\section{Data extraction}

Information about publication (first author's surname, year of publication, etc.), study design, number of samples studied, results of each article were extracted by two independent researchers. The observed differences in the evaluation of studies were solved by a third researcher. Based on the type of design study, specific qualitative methodology checklist for Quality Assessment was used.

\section{Results}

In this review, 1203 individuals were analyzed in the 10 selected articles in English including two randomized clinical trial, two cross-sectional, and two qualitative studies. It can be seen in Table 2 indicating the results of the study eligible for the study. The process of search and selection of gathered articles based on PRISMA guidelines shows in Figure 1.

\section{Discussion}

Taking into account the style of writing in a systematic review, the results of 10 studies in the field of supportive-

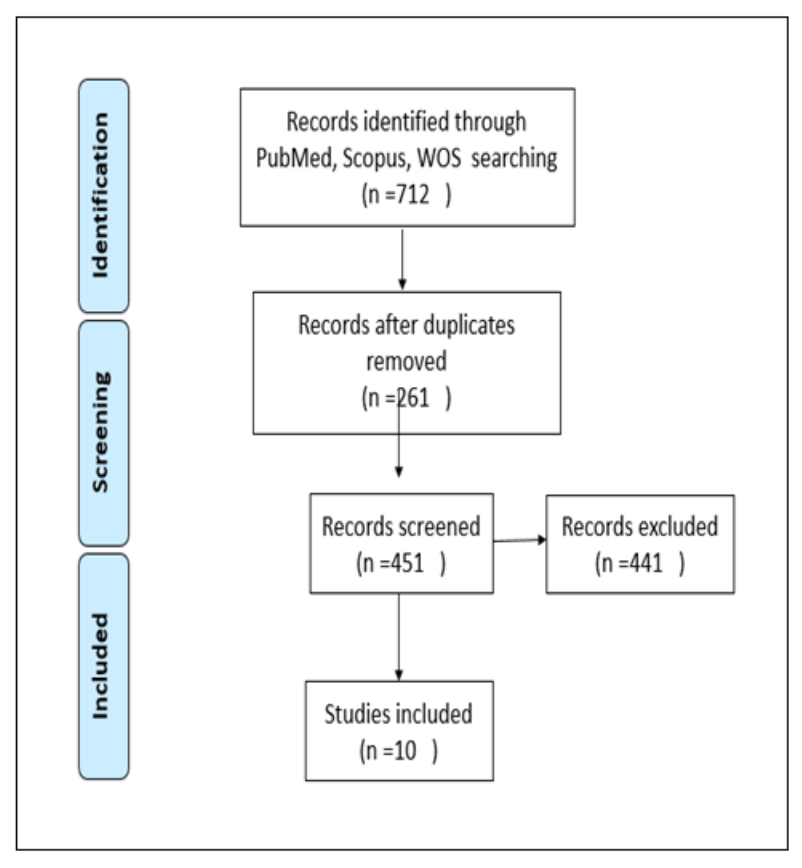

Figure 1. Process of Selection Documents Related to Breast Cancer According to PRISMA Guidelines 
Table 1. Quality of Materials, Methods, Data, and the Key Component of the Final Articles

\begin{tabular}{lll}
\hline \multicolumn{2}{l}{ Question } & Score \\
\hline 1 & Are the research questions clearly stated? & No $=0$ Yes $=1$ \\
2 & Is the approach appropriate for the research question? & No $=0$ Yes $=1$ \\
3 & Is the study context clearly described? & No= $=0$ Yes $=1$ \\
4 & Is the role of the researcher clearly described? & No $=0$ Yes $=1$ \\
5 & Is the sampling method clearly described? & No $=0$ Yes $=1$ \\
6 & Is the sampling strategy appropriate for the research question? & No= $=0$ Yes $=1$ \\
7 & Is the method of data collection clearly described? & No $=0$ Yes $=1$ \\
8 & Is the data collection method appropriate to the research question? & No=0 Yes $=1$ \\
9 & Is the method of analysis clearly described? & No=0 Yes $=1$ \\
10 & Are the main characteristics of the population well described? & No $=0$ Yes $=1$ \\
11 & Is the analysis appropriate for the research question? & No=0 Yes $=1$ \\
12 & Are the claims made supported by sufficient evidence? & No=0 Yes $=1$ \\
\hline
\end{tabular}

therapeutic interventions in women with breast cancer and body image problems were put together. This systematic review showed that a variety of interventions can be useful to reduce the problem of women with breast cancer. Our study showed some effective factor in the improvement of patients with breast cancer including family support, supportive programs, physically and psychologically support with family and relatives, holistic care, psychological screening and consultation, social support, family involvement in the treatment process of women with breast cancer. The study by Izadi et al. in 2013 showed that behavioral-cognitive therapy has been effective in changing body image scores, because it separates thoughts from feeling and searches for patient resistance to help challenge mental disorders to solve problems due to the body image, and then focuses on enhancing the changes [21].

It should be noted that patients with a loss of breast and changes such as deformity and scars experience have different attitudes about their sexual identity affecting the individual and interpersonal relationships of patients. Therefore, the presence of interventions is effective in diminishing the problems, increasing awareness and changing their attitudes, which is consistent with the studies of Izadi et al., Lotfi et al. and Salonen [21-23]. On the other hand, the presence of problems in the pathway for treatment and surgery provides a lot of stress and interpersonal problems, and studies acknowledge that interventions have been effective in reducing patient concerns. These results are consistent with the study of Shariati et al. which revealed the main effect of relaxation in improving the quality of life and body image [24].

Consultation for improving mental disorders of patient with breast cancer is one of the main methods that must be considered [25]. A review of past research shows that physical image can play a significant role in the psychological functions of women with breast cancer. One of the important issues in the psychological functions is self-esteem [26, 27]. In this regard, Bakht and Najafi in a study entitled body image and sexual problems in people with breast cancer and healthy individuals, reported that a variety of treatments for breast cancer had a particular effect on body image, menopause, and eventuality sexual problems and cancer patients have lower scores in all body scales od body image compared to healthy people [28].

Rizlar et al. found out that there is a negative significant correlation between sub-scales of the social support scale and sub-scales of the psychosocial aspects, as well as there is a negative significant correlation between confidence support and health care awareness. Social support for patients with breast cancer has changed their psychosocial adjustment to cancer. Comprehensive care is necessary for patients with breast cancer by nurses especially in the first six months of treatment as well as by their family and relatives in treatment process. The main finding is that their family should be paid more attention regarding physical and psychological support, indeed, patients with breast cancer need deeply domiciliary care [18]. These results are consistent with the study of Northouse et al., indicating family support effect on improvement in life quality in cancer patients [29].

The study of Tabrizi and Alizadeh demonstrated that the support of family members for patients with breast cancer plays a main role for coping with cancer [19], which was consistent with the conclusion of our study. Now we beilve that survival and management of cancer is multifactorial affected by geography, being supported by others, medicine, mental help and so on [30-36]. Family can be the first effective step for treating problems due to cancer treatment given their emotional relationships and sympathy with patient and the times spending along with family members.

\section{References}

1. DeSantis CE, Fedewa SA, Goding Sauer A, Kramer JL, Smith RA, Jemal A. Breast cancer statistics, 2015: Convergence of incidence rates between black and white women. CA: a cancer journal for clinicians. 2016 02;66(1):31-42. https:// doi.org/10.3322/caac. 21320

2. Jazayeri SB, Saadat S, Ramezani R, Kaviani A. Incidence of primary breast cancer in Iran: Ten-year national cancer registry data report. Cancer Epidemiology. 2015 08;39(4):519-527. https://doi.org/10.1016/j.canep.2015.04.016

3. Pikler V, Winterowd C. Racial and Body Image Differences 
Table 2. The Detail of Studies Entered into Systematic Review

\begin{tabular}{|c|c|c|c|c|c|c|}
\hline ID & Reference & Title & $\begin{array}{c}\text { Sample } \\
\text { size }\end{array}$ & Design & $\begin{array}{c}\text { Age } \\
(\text { Mean } \pm \text { SD })\end{array}$ & Conclusion \\
\hline 1 & $\begin{array}{l}\text { Rodrigues } \\
\text { Guedeset al. } \\
\text { in } 2018[11]\end{array}$ & $\begin{array}{l}\text { Body Image of Women Submitted to } \\
\text { Breast Cancer Treatment }\end{array}$ & 103 & Cross-sectional & $55.97 \pm 10.6$ & $\begin{array}{l}\text { The immediately need for programs } \\
\text { consisted of consultations, psychosocial } \\
\text { support and screening for patients with } \\
\text { breast cancer is necessary. }\end{array}$ \\
\hline 2 & $\begin{array}{l}\text { Suwankhong } \\
\text { et al. in } 2018 \text { [12] }\end{array}$ & $\begin{array}{l}\text { Physical and Emotional Experiences } \\
\text { of Chemotherapy: a Qualitative Study } \\
\text { among Women with Breast Cancer in } \\
\text { Southern Thailand }\end{array}$ & 20 & Qualitative & Not reported & $\begin{array}{l}\text { Social support programs reduce the } \\
\text { sufferings of patients with breast cancer. } \\
\text { Skilled nurses in cooperation with other } \\
\text { health care personnel may play t } \\
\text { important role to hold such group. }\end{array}$ \\
\hline 3 & $\begin{array}{l}\text { Hamzehgardeshi } \\
\text { et al. in } 2017 \text { [13] }\end{array}$ & $\begin{array}{c}\text { Effect of Midwifery-Based } \\
\text { Counseling Support Program on } \\
\text { Body Image of Breast Cancer Women } \\
\text { Survivors }\end{array}$ & 106 & $\begin{array}{l}\text { Randomized } \\
\text { clinical trial }\end{array}$ & $\begin{array}{l}\text { Intervention: } \\
46.77 \pm 6.85 \\
\text { Control: } \\
48.92 \pm 5.86\end{array}$ & $\begin{array}{l}\text { Support programs have a positive effect } \\
\text { on the body image of patients with breast } \\
\text { cancer and support programs should be } \\
\text { considered as an effective way for } \\
\text { survivors of breast cancer. }\end{array}$ \\
\hline 4 & $\begin{array}{l}\text { Peerawong } \\
\text { et al. in } 2016[14]\end{array}$ & $\begin{array}{c}\text { Breast Conserving Therapy and } \\
\text { Quality of Life in Thai Females: } \\
\text { a Mixed Methods Study }\end{array}$ & 118 & $\begin{array}{l}\text { Sequential } \\
\text { mixed }\end{array}$ & $52.00 \pm 9.00$ & $\begin{array}{l}\text { Body image influences the quality of life. } \\
\text { In this case, the conserved breasts lead to } \\
\text { better and positive status of body image } \\
\text { as a main section of life. }\end{array}$ \\
\hline 5 & $\begin{array}{l}\text { Abu-Helalah } \\
\text { et al. in } 2014 \text { [15] }\end{array}$ & $\begin{array}{l}\text { Quality of Life and } \\
\text { Psychological Well-Being of Breast } \\
\text { Cancer Survivors in Jordan }\end{array}$ & 236 & Cross-sectional & $50.7 \pm 10.7$ & $\begin{array}{l}\text { Psychological wellbeing of breast cancer } \\
\text { survivors is not suitable and has reported } \\
\text { more impaired. Psychosocial support } \\
\text { programs and consultation for patients } \\
\text { with breast cancer are crucial. }\end{array}$ \\
\hline 6 & $\begin{array}{l}\text { Chang et al. } \\
\text { in } 2014 \text { [16] }\end{array}$ & $\begin{array}{c}\text { Association between } \\
\text { Socioeconomic Status and Altered } \\
\text { Appearance Distress, Body Image, } \\
\text { and Quality of Life Among Breast } \\
\text { Cancer Patients }\end{array}$ & 126 & Cross-sectional & $47.7 \pm 8.4$ & $\begin{array}{l}\text { Socioeconomic status is associated with } \\
\text { distress following altered appearance, } \\
\text { quality of life and body image in patients } \\
\text { with breast cancer. Health care providers } \\
\text { should consider such distresses and } \\
\text { provide specific information and } \\
\text { psychosocial support to vulnerable } \\
\text { patients. }\end{array}$ \\
\hline 7 & $\begin{array}{l}\text { Keskin and } \\
\text { Gumus } \\
\text { et al. in } 2011 \text { [17] }\end{array}$ & $\begin{array}{c}\text { Turkish Hysterectomy and } \\
\text { Mastectomy Patients Depression, } \\
\text { Body Image, Sexual Problems and } \\
\text { Spouse Relationships }\end{array}$ & 94 & Cross-sectional & $47.78 \pm 9.80$ & $\begin{array}{l}\text { Body image following mastectomy is } \\
\text { related to more depression as well as } \\
\text { hysterectomy is accompanied with } \\
\text { greater sexual problems and difficulties } \\
\text { with husband. }\end{array}$ \\
\hline 8 & $\begin{array}{l}\text { Rizalar et al. } \\
\text { in } 2014[18]\end{array}$ & $\begin{array}{l}\text { Effect of Perceived Social Support on } \\
\text { Psychosocial Adjustment of Turkish } \\
\text { Patients with Breast Cancer }\end{array}$ & 100 & Cross-sectional & $52.60 \pm 10.52$ & $\begin{array}{l}\text { Psychosocial adjustment to cancer can be } \\
\text { achieved by social support for patients } \\
\text { with breast cancer. Comprehensive care } \\
\text { should be done for patients with breast } \\
\text { cancer by nurses working in oncology } \\
\text { department especially in the early periods } \\
\text { of treatment. Patients accompanied by } \\
\text { their family in the process of treatment } \\
\text { and care get better results, and their } \\
\text { family must look after them in terms of } \\
\text { physically and psychologically support. } \\
\text { Domiciliary care should be provided for } \\
\text { them. }\end{array}$ \\
\hline 9 & $\begin{array}{l}\text { Tabrizi and } \\
\text { Alizadeh } \\
\text { et al. in } 2014 \text { [19] }\end{array}$ & $\begin{array}{l}\text { Family Intervention Based on the } \\
\text { FOCUS Program Effects on Cancer } \\
\text { Coping in Iranian Breast Cancer } \\
\text { Patients: a Randomized Control Trial }\end{array}$ & 60 & $\begin{array}{l}\text { Randomized } \\
\text { clinical trial }\end{array}$ & $\begin{array}{l}\text { Intervention: } \\
47.03 \pm 7.73 \\
\text { Control: } \\
46.16 \pm 7.59\end{array}$ & $\begin{array}{l}\text { Family involvement in patients with } \\
\text { breast cancer using FOCUS program can } \\
\text { increase the ability to cope with breast } \\
\text { cancer in survivors. }\end{array}$ \\
\hline 10 & $\begin{array}{l}\text { Ardahan and } \\
\text { Yesilbalkan } \\
\text { et al. in } 2010[20]\end{array}$ & $\begin{array}{l}\text { Perceived Family Support of Women } \\
\text { with Breast Cancer and Affecting } \\
\text { Factors in Turkey }\end{array}$ & 240 & Cross-sectional & Not reported & $\begin{array}{l}\text { Perceived family support among patients } \\
\text { with breast cancer is essential and } \\
\text { reasonable. }\end{array}$ \\
\hline
\end{tabular}

in Coping for Women Diagnosed With Breast Cancer. Health Psychology. 2003;22(6):632-637. https://doi. org/10.1037/0278-6133.22.6.632

4. Aguilar Cordero MJ, Mur Villar N, Neri Sánchez M, PimentelRamírez ML, García-Rillo A, Gómez Valverde E. Breast cancer and body image as a prognostic factor of depression: a case study in México City. Nutricion Hospitalaria. 2014 Dec 01;31(1):371-379. https://doi.org/10.3305/ nh.2015.31.1.7863

5. Sabiston C, Rusticus S, Brunet J, McDonough M, Hadd V, Hubley A, Crocker P. Invariance test of the Multidimensional
Body Self-Relations Questionnaire: Do women with breast cancer interpret this measure differently?. Quality of life research : an international journal of quality of life aspects of treatment, care and rehabilitation. 2010 Oct 01;19:117180. https://doi.org/10.1007/s11136-010-9680-y

6. Parizadeh H, Hasan Abadi H, Mashhadi A, Taghizadeh Kermani A. Investigating effectiveness of existential and reality group-therapy in treatment of body-image problem in women who undergo mastectomy. The Iranian Journal of Obstetrics, Gynecology and Infertility 2012; 15(22):27-35 (In Persian). 
7. Ganz PA, Yip CH, Gralow JR, Distelhorst SR, Albain KS, Andersen BL, Bevilacqua JLB, Azambuja E, El Saghir NS, Kaur R, McTiernan A, Partridge AH, Rowland JH, Singh-Carlson S, Vargo MM, Thompson B, Anderson BO. Supportive care after curative treatment for breast cancer (survivorship care): resource allocations in low- and middle-income countries. A Breast Health Global Initiative 2013 consensus statement. Breast (Edinburgh, Scotland). 2013 Oct;22(5):606-615. https://doi.org/10.1016/j. breast.2013.07.049

8. Leilabady, F. Nassiri ziba, M. Nazari Geirani, F. Hosseini. Patients with Breast Cancer and Their Needs. IJN. 2005; 17 (40) :28-38.

9. Hoffman AJ, Eye A, Gift AG, Given BA, Given CW, Rothert M. Testing a Theoretical Model of Perceived Self-Efficacy for Cancer-Related Fatigue Self-Management and Optimal Physical Functional Status. Nursing research. 2009;58(1):3241. https://doi.org/10.1097/NNR.0b013e3181903d7b

10. Shoaa kazemi M. Relation between family social support \& coping strategies in recovery breast cancer. ijbd. 2014; $6(4): 35-40$.

11. Guedes TSR, Dantas de Oliveira NP, Holanda AM, Reis MA, Silva CP, Rocha e Silva BL, Cancela MDC, Souza DLB. Body Image of Women Submitted to Breast Cancer Treatment. Asian Pacific journal of cancer prevention: APJCP. 201806 25;19(6):1487-1493. https:// doi.org/10.22034/APJCP.2018.19.6.1487

12. Suwankhong D, Liamputtong P. Physical and Emotional Experiences of Chemotherapy: a Qualitative Study among Women with Breast Cancer in Southern Thailand. Asian Pacific Journal of Cancer Prevention : APJCP. 2018;19(2):521528. https://doi.org/10.22034/APJCP.2018.19.2.521

13. Hamzehgardeshi Z, Moosazadeh M, Elyasi F, Janbabai G, Rezaei M, Yeganeh Z, Alashti MR. Effect of MidwiferyBased Counseling Support Program on Body Image of Breast Cancer Women Survivors. Asian Pacific Journal of Cancer Prevention : APJCP. 2017;18(5):1293-1299. https:// doi.org/10.22034/APJCP.2017.18.5.1293

14. Peerawong T, Phenwan T, Supanitwatthana S, Mahattanobon $\mathrm{S}$, Kongkamol C. Breast conserving therapy and quality of life in Thai Females: a mixed methods study. Asian Pac J Cancer Prev. 2016;17(6):2917-21.

15. Abu-Helalah M, Al-Hanaqta M, Alshraideh H, Abdulbaqi N, Hijazeen J. Quality of life and psychological well-being of breast cancer survivors in Jordan. Asian Pacific journal of cancer prevention: APJCP. 2014;15(14):5927-5936. https:// doi.org/10.7314/apjcp.2014.15.14.5927

16. Chang O, Choi E, Kim I, Nam S, Lee JE, Lee SK, Im Y, Park YH, Cho J. Association between socioeconomic status and altered appearance distress, body image, and quality of life among breast cancer patients. Asian Pacific journal of cancer prevention: APJCP. 2014;15(20):8607-8612. https:// doi.org/10.7314/apjcp.2014.15.20.8607

17. Keskin G, Gumus AB. Turkish hysterectomy and mastectomy patients-depression, body image, sexual problems and spouse relationships. Asian Pac J Cancer Prev. 2011 Jan $1 ; 12(2): 425-32$.

18. Rizalar S, Ozbas A, Akyolcu N, Gungor B. Effect of perceived social support on psychosocial adjustment of Turkish patients with breast cancer. Asian Pacific journal of cancer prevention: APJCP. 2014;15(8):3429-3434. https:// doi.org/10.7314/apjcp.2014.15.8.3429

19. Tabrizi FM, Alizadeh S. Family Intervention Based on the FOCUS Program Effects on Cancer Coping in Iranian Breast Cancer Patients: a Randomized Control Trial. Asian Pacific Journal of Cancer Prevention : APJCP. 2018;19(6):1523-
1528. https://doi.org/10.22034/APJCP.2018.19.6.1523

20. Ardahan M, Yeşilbalkan Ö. Perceived Family Support of Women with Breast Cancer and Affecting Factors in Turkey. Asia Pac J Cancer Prev. 2010 Jan 1;11: 1425-9.

21. Izadi-Ajirlo A, Bahmani B, Ghanbari-Motlagh A. Effectiveness of cognitive behavioral group intervention on body image improving and increasing self-esteem in women with breast cancer after mastectomy. Quarterly Journal of Rehabilitation 2013; 13(4):72-83 (In Persian).

22. Kashani FL, Vaziri S, Akbari ME, Far ZJ, Far NS. Sexual skills, sexual satisfaction and body image in women with breast cancer. Procedia-Social and Behavioral Sciences 2014; 159:206-13.

23. Salonen P, Tarkka M, Kellokumpu-Lehtinen P, Astedt-Kurki P, Luukkaala T, Kaunonen M. Telephone intervention and quality of life in patients with breast cancer. Cancer Nursing. 2009 06;32(3):177-190; quiz 191-192. https://doi. org/10.1097/NCC.0b013e31819b5b65

24. Shariati A, Salehi M, Ansari M, Latifi SM. Survey the effect of Benson relaxation intervention on quality of life (QOL) in breast cancer patients undergoing chemotherapy. Jundishapur Scientific Medical Journal 2010;9(6):625-32 (In Persian).

25. Heravi Karimoui M, Pourdehghan M, Jadid Milani M, Foroutan SK, Aieen F. Study of the effects of group counseling on quality of sexual life of patients with breast cancer under chemotherapy at Imam Khomeini Hospital. Journal of Mazandaran University of Medical Sciences 2006;16(54):43-51 (In Persian).

26. Meraviglia M. Effects of spirituality in breast cancer survivors. Oncology Nursing Forum. 200601 01;33(1):E1-7. https://doi.org/10.1188/06.ONF.E1-E7

27. Moreira H, Canavarro MC. A longitudinal study about the body image and psychosocial adjustment of breast cancer patients during the course of the disease. European Journal of Oncology Nursing: The Official Journal of European Oncology Nursing Society. 2010 09;14(4):263-270. https:// doi.org/10.1016/j.ejon.2010.04.001

28. Bakht S, Najafi S. Body image and sexual dysfunctions: comparison between breast cancer patients and healthy woman, Procedia social and behavior of sciences. 2010;5:1493-7. https://doi.org/10.1016/j.sbspro.2010.07.314

29. Northouse LL, Katapodi MC, Schafenacker AM, Weiss D. The impact of caregiving on the psychological well-being of family caregivers and cancer patients. Seminars in Oncology Nursing. 2012 Nov;28(4):236-245. https://doi.org/10.1016/j. soncn.2012.09.006

30. Zareipour MA, Mahmoodi H, Valizadeh R, Ghelichi Ghojogh M, Rezaie Moradali M, Zare F. Impact of an Educational Intervention Based on the BASNEF Model on Skin Cancer Preventive Behavior of College Students. Asian Pacific journal of cancer prevention: APJCP. 2018 Oct 26;19(10):2717-2722. https://doi.org/10.22034/ APJCP.2018.19.10.2717

31. Pordanjani SR, Baeradeh N, Khazaei Z, Goodarzi E, Beiranvand R, Alikhani A, Sohrabivafa M, Valizadeh R. Epidemiological Trend and Distribution of Prevalent Cancers in Razavi Khorasan Province during 2005-2010, Iran. International Journal of Preventive and Public Health Sciences. 201609 30;2(5):8-12. https://doi.org/10.17354/ ijpphs/2016/47

32. Khalkhali HR, Gharaaghaji R, Valizadeh R, Kousehlou Z, Ayatollahi H. Ten Years' Survival in Patients with Cervical Cancer and Related Factors in West Azerbaijan Province: Using of Cox Proportion Hazard Model. Asian Pacific journal of cancer prevention: APJCP. 201905 25;20(5):1345- 
1351. https://doi.org/10.31557/APJCP.2019.20.5.1345

33. Tabrizi FM, Alizadeh S, Barjasteh S. Managerial SelfEfficacy for Chemotherapy-Related Symptoms and Related Risk Factors in Women with Breast Cancer. Asian Pacific Journal of Cancer Prevention : APJCP. 2017;18(6):15491553. https://doi.org/10.22034/APJCP.2017.18.6.1549

34. Tabrizi F, Alizadeh S, Barjasteh S. The Investigation of the Relationship Between Cancer Coping and Symp-tom Management Self-Efficacy, Perceived Social Support, Uncertainty and Life Orientation in Breast Cancer Female Survivors. Scientific Journal of Hamadan Nursing \& Midwifery Faculty. 201902 23;26. https://doi.org/10.30699/ sjhnmf.26.1.1

35. Moghaddam Tabrizi F, Vahdati S, Khanahmadi S, Barjasteh S. Determinants of Breast Cancer Screening by Mammography in Women Referred to Health Centers of Urmia, Iran. Asian Pacific journal of cancer prevention: APJCP. 201804 25;19(4):997-1003. https://doi.org/10.22034/ APJCP.2018.19.4.997

36. Farnam F, Khakbazan Z, Nedjat S, Razavi Dizaji S, Barjasteh S. The Effect of Good Enough Sex (GES) Model-Based Sexual Counseling Intervention on the Body Image in Women Surviving Breast Cancer: A Randomized Clinical Trial. Asian Pacific Journal of Cancer Prevention : APJCP. 2021 07;22(7):2303-2310. https://doi.org/10.31557/ APJCP.2021.22.7.2303

\section{(ब) $(\Theta)$}

This work is licensed under a Creative Commons AttributionNon Commercial 4.0 International License. 